\title{
Creating a Hero ... Laughing at Clowns? Representations of Sports and Fitness in Soviet Fiction Films after the Olympic U-Turn in Politics
}

\author{
Andrey S. Adelfinsky \\ Candidate of Economic Sciences, Associate Professor, Bauman Moscow State Technical University \\ Address: Baumanskaya 2-ya, 5, Moscow, Russian Federation 105005 \\ E-mail: adelfi@mail.ru
}

\begin{abstract}
In the 1940s-196os, the USSR made an ideological turn from leftist sports politics to the struggle for Olympic achievements. How has this U-turn affected the social order in Soviet sport and its artistic representation? The article offers a systematic review of Soviet sport fiction films. The study of sport and fitness imagination is conducted through a correlation between artistic performance and social context. Focusing on the 1950s-1980s, we found three different types of representation: № 1 is the creating of a hero (for an elite athlete). This is the lion's share of all sport movies where the "Myth of a Hero" in Olympic sport was constructed. In praising elite sport, modern Russian movies continue the well-known Soviet tradition; № 2 is the laughing at clowns (for mass sportsmen). These are mostly episodes in feature films on themes, where mass sport (i.e., non-elite, grassroots, recreational, fitness, and ordinary) is mentioned. Surprisingly, this sport is presented in a comic sense (except hiking and mountaineering); №3 is sport reality. This type comprises the tiniest selection of movies where art reflects the real situation inside the Soviet sport industry. Elite athletes are presented here as antiheroes with social adaptation problems; additionally, such issues as shamateurism are severely criticized. The conclusions are following: since the 1970s, sport films ceased to function as propaganda of fitness and recreational sport. On the contrary, elite sport (as an art branch), its representations in official arts and media jointly constructed the great "evangelical myth" about itself, which became the part of public consciousness. However, this myth had little to do with a new reality. Elite sport's positive representation acted only as a propagandist tool that created a fictional social world. The existing social order's irrationality was critically reflected only by the comedy genre.
\end{abstract}

Keywords: sport policy, sport in art, Soviet cinema, social order, Soviet sport, sports pyramid, elite sport, sport for all

\section{The Hero Returns}

Naming a few, Legend No. 17, Going Vertical, The Match, The Champions, The Coachover the last decade, Russian cinema has produced an impressive collection of sport movies. The filmmakers' interest is a consequence of the last decade's series of mega-events in Russia, and, in the meantime, it is the continuation of official policy. Top-class sport and its artistic representation are positioned as a means to motivate citizens to physical activities, a production of role models, and a reason to be proud of Russian national history. As Russian President Vladimir Putin said at the Legend No. 17 premiere, this is "a good movie that will certainly find its audience both among sports fans, and those who 
are proud of their country's achievements" (2013). How does an artistic ideal correspond to the real state of affairs? What was Soviet sport like in reality? How was it presented in Soviet cinema?

The relationship between the reality of Soviet sports and its artistic reflection has been studied in the Mike O'Mahony monograph (2006). However, the main focus here was made on the visual arts of the 1920s-1940s, while the cinema of the 1950s-1980s has remained behind the scenes. Some works of Russian authors only marginally close this gap. Accordingly, our study, perhaps the first of today's attempt at a systematic review, reveals more than 80 Soviet fiction films variously related to sports. The results extend the theoretical view of art as a "barometer" of the attitudes and tensions within ideology and culture as well as the view of Soviet sports movies as a propaganda tool for the production of a "Heroic Myth". This "Myth" was actually produced, but the overall picture was different and not at all uniform. Our work is also a contribution to the contemporary polemic around the "evangelical myth" of the "inspiring" function of elite sports for the mass sports engagement (Grix, Carmichael, 2012).

The purposes of our research are to discuss the difference between the artistic performance and the existing social order, as well as the contribution of the former to the production of this "evangelical myth" by studying the sports and fitness representation in Soviet fictional films from 1950s-1980s.

The structure of this article is as follows: as a starting point, we describe the "Olympic" metamorphosis of the social order in Soviet sports, when the USSR, instead of the struggle against "recordism and championism" as "bourgeois perversions in sports", proceeded to their promotion. What follows is an overview of the academic studies exploring the artistic, and particularly the cinematic, representation of Soviet sport. Then, we outline the results of our systematic review, distinguishing three different types of sports representation in the Soviet cinema. Finally, we conclude by summarizing and discussing our findings.

\section{The Olympic Order and Its Alternatives from the "Left" in the 1920s-1930s}

The modern order in global sport resembles the feudal model a bit, where the Sovereign, being the source of honor, majesty, and glory, possesses the exclusive right to grant noble titles. Likewise, the International Olympic Committee (the IOC), is the "source of Olympism" with the exclusive right of co-optation into the Olympics, and the same right to recognize a solitary governing body for each athletic discipline. By managing its Olympics, the IOC positions them as the number one event in global sports. This is a championship of championships, where only the best athletes, the so-called Elite, compete. The steps below are the Championships and Cups: first the "World", then the "Continents", and then the "Nations". The base of this construction is the grassroots, or the mass level sport. According to the IOC's logic, the sport as a whole is a pyramid of qualifying competitions, with the Olympics at the top. 
Today, national governments support this "Olympic order" and invest in high sports performance for reasons of international prestige, trying to encourage and strengthen the identities of their nations by means of sport achievements. Moreover, this is typical for rather diverse political regimes: it is as true for the contemporary UK and Russia as it was for East Germany and the USSR in the recent past (Dennis, Grix, 2012; Adelfinsky, Anashvili, 2018).

During the inter-war period, however, the IOC was neither the monopoly-owner of the Olympics, nor the sole source of social order in global sports. There were two more "sovereigns": the Lucerne or Socialist Workers' (LSI/SASI) and the Red (RSI) Sport Internationals. Regarding the sport under the IOC's auspices as a "reactionary" bourgeois phenomenon, these two "sovereigns" promoted an alternative view of sports from the "left". Moreover, they held their own international Olympics and Spartakiads (Krüger, 2014; Physick, 2017; Strożek, 2018). Left-wing sports ideologues criticized the IOC for promoting nationalism and an addiction for records, and, as a result, effectively turning sports into an elite engagement (in terms of athletic performance), which slides into professionalism. Declaring the ideals of amateur sport, the IOC has practically contributed to the rise of shamateurism (i.e., pseudo-amateurism) (Llewellyn, Gleaves, 2012). The order of "Left" sports was discussed and actively put into practice in the 1920-1930s. For example, the Soviet Industry of Physical Culture and Sports (with the abbreviation of FKiS) was conceived as a sub-sector of the Health industry in the USSR. Its initial purpose was to develop mass-grassroots sport engagement whose tasks were to prepare army reserves and to provide health awareness. Both Recordism and Championism were declared to be "bourgeois sports perversions" that had to be overcome (Kedrov, 1928). These two sources of sports order from the left shared the similar ideological vision. The split took place along the line of political views of socialist reformism vs. communism. The rise of Popular Fronts as left-wing, anti-fascist international coalitions brought these two organizations closer. The RSI joined the unified SASI People's Olympics in spite of the IOC Berlin Olympics 1936, which were considered to be pro-Nazi.

\section{Soviet Sport: From Struggle against "Perversions" to Their Propaganda}

However, Soviet leaders decided to join the IOC Olympic movement in 1948, having put its recent past into oblivion. The decision of 1948 and a number of subsequent ones taken in the same vein led to the total degeneration of the previous Soviet sports order. Previously-criticized shamateurism had become an unspoken norm. Gradually, the functional meaning of the entire Soviet sport industry was reduced only to "setting records" and the best results at the IOC Olympics. Yuri Vlasov described the new order imposed by the end of 1960 s as "Everything, even the formation of sport classes in small provincial towns, is brought to the achievement of the main task: records, gold medals" (1986). At the same time, the initial purpose of achieving mass sports involvement outside the dependence upon skills and talent was lost. The still-declared course of "mass sport development" had become just an empty phrase, a familiar figure in official rhetoric. The 
allegory of "Turn left then drive right" was used by Sergei Pavlov, the head of Soviet sports from 1968-1983, when he was describing the real policy of his ministry in private conversations (Adelfinsky, 2018: ch. 1). The pressure from the top gave rise to the weird phenomenon of "double" shamateurism when the grassroots sports executives hired elite athletes to fake local low-level participation in order to demonstrate the desired sports achievements.

The "Olympic" transformation of Soviet sport was promoted from the top for reasons of international prestige. However, the new order was criticized from below by reflective industry insiders as early as the 1960s. With the beginning of the period of Perestroika, this criticism intensified so that the discussion among specialists continued even in the 20oos. Most experts (Alexander Vlasov, Yuri Vlasov, Pyotr Vinogradov, Anatoly Isaev, Lev Matveev, Oleg Milstein, and many others) agreed that the degradation of mass sports development in the late USSR was the result of an excessive concentration on Olympic success. The problem had an institutional and economic background and was caused by the changes in the distribution of resource flows, as well as "the rules of the game" (i.e., institutions). Using Thomas Mores' allegory, elite athletes "ate up and swallowed down" the mass sportsmen (Ibid.).

In addition to the negative impact of elite sports on mass grassroots sporting activity, a number of problems were pointed out in this discussion, such as extremely high maintenance costs and the overproduction in elite sports, as well as actual professionalization already at the level of reserve training (i.e., for school-age athletes). Among the consequences were the loss of the civic socialization of elite athletes, and failures in their education and upbringing. Together with "fame's burden", this resulted in a low cultural intelligence and the flawed morality of "sports heroes", even more often in their social alienation after their bright but brief athletic careers. Another consequence was the issue of the low level of intelligence among trainers and coaches recruited from the same environment. The doping problem was also in this "education pack" due to lack of scientific knowledge (Ibid.).

So, although sport is sometimes described as "an ideal of social order" (Katzer, 2018), the conclusion from the experts' discussion above is that the established "pro-Olympic" order in the USSR was not recognized either as fair or reasonable. The real "sports heroes" were not at all the "role models" one would expect as a side-effect of their production.

\section{Sport Visualizations in Soviet Art}

How was the "Olympic" transformation of Soviet sports reflected in art? Mike O'Mahony argues that the popular image of Soviet physical culture and sports depended as much on its actual practice as on its artistic representation. His research distinguishes clear periods within this artistic depiction of Soviet sports. The first period is the 1920s-1930s. Sports were promoted in the artworks of such masters as Alexander Deineka, Alexander Samokhvalov, Elena Yanson-Manizer, Alexander Rodchenko, Gustav Klutsis, Joseph Chaikov, and many others. Visual images glorify athletic engagement, but not rooting, cheering, or 
spectatorship. The portrayed heroes of sports are non-elite athletes, ordinary sportsmen and women (so-called fizkulturniks, i.e., physical-culturists, or exercisers), unnamed-butreal physically-strong people, the future defenders of the Land of Soviets and the working class: "You might not all be athletes, but to be a fizkulturnik is your duty" - proclaims the slogan on the famous advertising poster Sportswoman (Deineka, 1930). In the front of the poster is a shapely girl in a tight T-shirt and shorts, throwing a discus. A little bit further, a young man is preparing to shoot a rifle. In the background, a group of athletes is running, while the motorcyclists are racing.

O'Mahony pays the most part of his attention to the artworks of this period due to their large number in the whole body of identified works. He notes that the lion's share of countless Soviet articles on art during the 1980 Moscow Olympics was also focused on the "masters of the past", like Deineka and Chaikov (2006: 185). Discussing the propagandist intentions of this era of artworks, O'Mahony writes that, in fact, it was hardly coercion since people really liked doing sports (10).

The next period begins with the struggle for Soviet dominance in international sports in the post-war period. As an exemplary depiction of a new era sports hero, O'Mahony mentions The Awards of World Champion Maria Isakova (Nikich, 1951). Having triumphantly opened the count of Soviet international victories in 1948-1950, this speed-skater was awarded the highest Soviet award, the Order of Lenin. However, there is no real sportswoman in the picture, only her bronze statuette and numerous awards, her gold medals, prize cups, and magnificent view from the window of her prestigious apartment. Another early talent is a young girl-athlete as a symbol of top sports reserve, doing morning exercises in the painting called The Morning (Yablonskaya, 1954). The portrayal of sport spectators, previously discouraged, also received its artistic legitimacy. The painting Football Fans may serve here an example (Tikhanovich, 1952). The final period of the USSR is the era of its steady success in Olympic sports, but this success no longer inspired the masters of painting and sculpture. O'Mahony writes: "from the mid-1960s ... the [sports] theme all but disappeared from the work of official artists" (2006: 176). All samples he mentions are the pieces of kitsch and satire performed by non-conformist artists such as Grigory Bruskin, Boris Orlov, Vitaly Komar, and Alexander Melamid. This thesis of a predominantly kitschy portrayal of sports in Soviet art since the mid-196os can probably be challenged by further research, but the presented timeline is, in our opinion, quite true.

\section{Cinema as a Propaganda Tool}

What about the representation of sports in cinema? Vladimir Padunov argues that both Western Slavic studies and film criticism regarded Russian and Soviet films as terra incognita until the last decades of the twentieth century. It was only in the 1990 os that certain works by Western authors were published (2011), and the journal Studies in Russian and Soviet Cinema appeared. Alexander Fedorov presented a number of valuable reviews $(2018,2020,2021)$. However, the topic of sports in these sources was not covered enough. 
In his monograph, O'Mahony mentions only a couple of films, one being the well-known movie, Goalkeeper (1936), based on the novel by Lev Kassil (1934), as well as the documentary Man with the Movie Camera by Dziga Vertov (1929). Dufraisse, while studying Soviet "sports heroes", briefly mentions only a small number of movies (2019). The cinematic material discussed in the works of Soviet and Russian authors is much more extensive. There are more or less detailed studies on specific film topics. Andrey Apostolov studied the goalkeeper's image together with the the transformation of the spectators' role in Soviet sport (2014a, 2014b). Other research topics include the myth and actual reality in elite gymnastics (Tsyrkun, 2007), sports television broadcasting as a show (Averkova, 2011), the image of a "new man" in 1930s' cinema (Fisheva, 2020), etc. The film critic Denis Gorelov presented a selection of fitness episodes in Soviet films (2019). His thesis of a kitschy fitness depiction in 1970s-1980s' Soviet film echoes that of O'Mahony.

There were some attempts to write reviews. Studying the on-screen image of an athlete in the array of ten Soviet and seven post-Soviet films, Ligostaeva noted its compliance to the social orders in different periods of Russian history. The "totalitarian" Stalinist sportsman-hero was gradually replaced since the Khrushchev Thaw by the image of a "reflective intellectual". In the late 1980s, the image of an athlete is already presented as a "crisis hero", whose mindset reflects a "sense of hopelessness and loss of values" in the whole of society. Later post-Soviet cinema practically does not produce sports movies. Then, in the last decade, Russian cinema creates the image of a "triumphant sports hero". In general, according to Ligostaeva, the athletic images of different eras have one common feature in that "All of them are heroes of their time and country". Her conclusion is that feature films about sports "are endowed with a clearly pronounced function of education, sometimes propaganda" (2020).

The propaganda tasks of art, however, were not concealed during the Soviet period. The sports film "propagandize the best human qualities: bravery, courage, determination". Its heroes are "the best representatives of our youth, whom sport helps to be agile, strong, and healthy" - writes Zlodoreva in the work Sports through the Eyes of Cinema, possibly the first Soviet catalog of sports films (1968). In his guidelines for the use of cinema in the propaganda of sports, Vinogradov indicates its principal mission. This is "the formation among the general population the idea of sport and physical culture (FKiS) as organic parts of the socialist way of life, a conscious attitude to physical exercises" (1979).

However, the artistic representation and the object of propaganda were markedly different. "The hero in sports film does not have a complex personality, he is as static and positive as possible," argue Isaev and Pozhidaeva, discussing three recent Russian biopics of last decade. They are writing about the films Match, Poddubny, and Legend No. 17. The researchers emphasize that the desired result of "positive identity formation" is a break with the academic knowledge that allows the highly-selective choice of facts, which simplifies the task of "myth construction" (2016).

The gap between sports films and reality was criticized in the Soviet era against the backdrop of rich cinematic material. Sports movies live "under the common hood of one and the same plot" since the days of Kassil's Goalkeeper (1936), as filmmaker Alexander 
Maryamov noticed critically in 1986 in the Soviet Culture newspaper, the official press of the Soviet Ministry of Culture and the Central Committee of Soviet Culture Employees Union. He stated the stable reproduction of a simple pattern in fictional sports films: "Somewhere a new sports talent was spotted. Someone brought this talent into the sport. Somehow, almost immediately this talent falls into arrogance and catches star sickness. Somehow, almost entirely on his/her own, this talent was re-educated and set on the right track back. In the end the talent surely wins by overcoming both his rivals and himself" (1986). It is noteworthy that the theoretical framework to which Ligostaeva refers is the popular mono-myth theorized by Joseph Campbell (1949), and explicated nowadays in Christopher Vogler's works (Vogler 1985). However, we believe that the Maryamov's slightly caricatured pattern seems to be a little more appropriate for the Soviet sports cinema. Also we cannot but help mention Vladimir Propp's The Morphology of the Folktale (1928). So, having outlined the theoretical framework, let us proceed to our review.

\section{Research Design}

According to Thomas Hobbes' prominent logic, the social order is maintained in a topdown manner by the power of the mighty Leviathan, whom subjects must obey in the name of the common good. However, the stability of social orders in the logic of Talcott Parsons, Jürgen Habermas, and Jeffrey C. Alexander depends on their "inner justice", that is, legality, morality, i.e., on the degree of their recognition and support from below (Turkulets, 2010; Kildyushov, 2016). Obviously, O’Mahony adheres to the second position: he considers art to be the "barometer" of sentiments, relations, and tensions within ideology and culture. At the same time, he challenges the common opinion of sports and physical culture propaganda in the USSR as just "totalitarian pressure" from authorities who forced the masses to exercise (O’Mahony, 2006: 9). In turn, the Russian authors reviewing Soviet sports cinema concluded that the art was a propaganda tool. However, the obvious disadvantage of previously known reviews is the coverage of the material is relatively small. As we will show below, the art had not only promoted the social order as imposed by authorities, but it also was the source of reflection on existing imperfections. Additionally, this order was sometimes ridiculed, and in some cases, even served as a tool of social criticism.

Our study is methodically based on a systematic review. The materials made by Zlodoreva and Vinogradov allowed us to identify 27 feature movies, each touching the subject of Soviet sports to some extent. In studying the catalogs of Soviet film studios and press materials, we found another forty-three movies on the theme of sport in the 1950s-1980s in compiling our own catalog. The review is also supplemented by episodes of sports from eleven films on other subjects. Pushing from the available sampling of fitness episodes (Gorelov, 2019), we supplemented it with a large number of top-grossing films (Fedorov, 2021). Note that our selection of episodes does not yet pretend to be a systematic one, rather serving as an additional illustration. Moving through this catalog, we identified the plot (more precisely, the fabula) of a movie (or an episode), classifying 
the material through two main questions: is it a recreational sport or an elite one with its reserves? Are we dealing with a "heroic myth" production, or with an actual reflection of social order (taking into account the "Olympic" transformation of the Soviet sport industry described above)?

As a result, we have distinguished three conceptual blocks. Selection № 1 gives a very brief description of the films wherein the myth of the athletic hero is actually constructed. Moreover, feature films depict the "Olympic order" here, that is, the world of elite sport and its reserve training. Selection № 2 is devoted to the topic of mass non-elite sports. The sole identified film (Seven Old Men and a Girl) is supplemented with several episodes' descriptions from general topics movies, where the theme of mass non-elite sports was somehow mentioned. Selection № 3 contains feature films that present criticism of Soviet sports, taking into account the "Olympic" transformation described above.

\section{Selection № 1: The Elite Athletes}

The central narrative of practically every Soviet sports movie is the victorious road to triumph in either international competitions or directly at the Olympics. The hero is an amateur athlete, professionally employed elsewhere. World Champion (1954) tells the story of a young blacksmith from a rural area somewhere in Russia who turns out to be a talented wrestler, and eventually wins the title. Rings of Glory (1962) is also a story of a blacksmith, but from an Armenian village, who became a world champion in artistic gymnastics. The New Girl (1968) is the story of a young florist-girl from a Moscow landscaping public utility who is fond of gymnastics, and becomes a member of the USSR national team. The film's opening and its promising conclusion suggest that the protagonist will be a worthy successor to the gold-winning Soviet Olympic gymnasts of the 1950s-196os. Miracle with Pigtails (1974) is about the same sport in the 1970s when female gymnastics teams were starting to be made up of schoolgirls. The lead character, a young girl, and her coach put cutting-edge performances and extremely complex, over-thetop elements into the practice. Overcoming resistance from retrogrades, they eventually achieve recognition and the highest marks from the judges. A Center from the Skies (1975) is a musical comedy about a young shepherd gifted in basketball, who plays for the team called "Student", and beats his American opponents in the last three seconds of the game. Faster than Your own Shadow (1980) tells the story of a student runner training hard for world-class competitions, and then for the Olympics. The Girl and Grand (1981) is about the joint road of a horse and a young lady-groom who then becomes a jockey achieving success at an international tournament. Movies with teenagers as main characters allow some local victories. Lost Summer (1964) is the story of a schoolboy who unexpectedly wins a cycling race. Tigers on Ice (1971) tells about a youth ice hockey team and their way to victory.

The obstacles on the hero's journey are usually his or her undesirable personal qualities in need of correction. Usually these are properties peculiar to young characters. They are about emotional instability, uncertainty, and weakness. Or, on the contrary, they are 

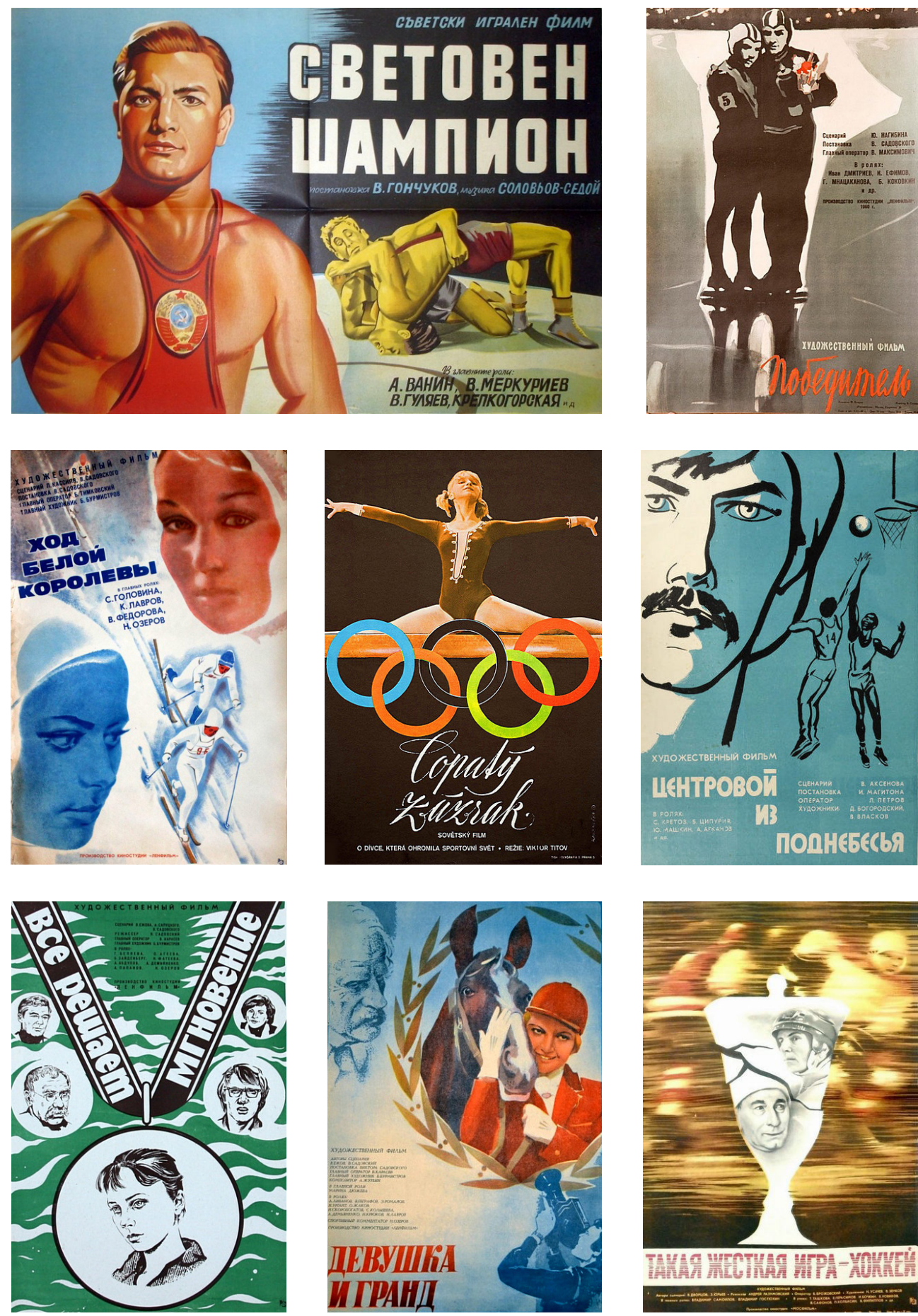

Typical view on Elite sport: “The Soviet Hero with a Thousand of Faces": World Champion (1955), Winner (1960), White Queen's Move (1971), Miracle with Pigtails (1974), Centerline from the Skies (1975), It's a Moment (1978), The Girl and the Grand (1981), Such a Tough Game-Hockey (1983) 
excessive self-confidence, arrogant on the verge of rudeness and impudence, or poor moral fiber. The logical consequence of overcoming this obstacle is a victory. Individual Championship (1963) is about the "eternal runner-up" boxer with an insufficient will to win. It is only the moral support of his rival-friend which allows him to become a champion. The drama may be based on the contrast of the characters or personal conflict. Blue Ice (1969) begins with a pair of figure skaters who lose a competition as a consequence of their mutual discord, but ends with their reunion. The storyline of A Royal Regatta (1966) is also built up from initial failure to final triumph.

Soviet sports movies actively promote the theme of the relationship between mature and young top-level athletes. One of main qualities of the social order displayed in these movies is the warm attitude of venerable athletes towards their young successors, and a smooth generational change. In the early comedy The Old Rider (1940), an experienced jockey retires to his native village, where he prepares the new horse-race winner out of a young groom. In The Winner (1960), a veteran speed-skater sacrifices his glory of an invincible champion for the sake of a new absolute track record set up by the young athlete, his trainee. Strict Game (1964) tells about the fate of a thirty-four-year-old retired soccer player who finds his new vocation in training young people. The New Girl (1968) also finds herself protected by an eminent female gymnast who becomes her mentor and friend, and then gives up her way on the podium and joins the audience. A veteran-rower in Light Water (1972) has long-term plans to end his sporting career. Only the absence of young successors makes him stay and, at the cost of a great effort, wins international competitions. In The Lot (1974), a senior hockey goalkeeper advice to junior one. Vocation (1975) tells the story about an experienced cyclist who dreams of coaching. He cedes his place on the team at a prestigious international race to a novice athlete. In Iron Games (1979), the world record becomes a farewell chord as a logical retribution for his generosity for the outgoing veteran, against the backdrop of his arrogant young rival.

The symbol of overcoming obstacles is the social class of coaches and trainers. Usually their characters serve as an embodiment of wisdom, great experience, and the ability to find an approach to their trainees. The support of a coach allows a teenager to master The Large Hill (1973). It's a Moment (1978) gives an example of empathetic leadership allowing the 15-year-old female swimmer to cope with the excitement of international competition. The head soccer coach is the central character of Eleven Hopes (1976), whose work in selecting and managing the USSR national team ultimately brings the desired success. Skiing in White Queen's Move (1971), soccer in Such a Game (1975) and Kick! Another kick! (1963) are also lined up around coaches as central figures. Sports leaders, heads, functionaries, and managers are closely connected to the class of coaches. The main narratives are discerned talent, brought up in a community, the road to success given to young people, invaluable help provided, etc. These managers of Soviet sport are the most serious and respectable characters in the early sports comedies like The First Glove (1946), Sporting Honor (1951), and The Reserve Player (1954).

Sport as an aid to everyday life is probably the educational motive of The Ring (1973). Its genre is unusual because it is both a sports film and a detective story. The main char- 
acter was an elite boxer five years earlier: he was a five-time national, world, and Olympic champion. Now, he is a police major investigating a robbery case, but the method of investigation is rather sophisticated. Since the robber is presumably a boxer, too, the boxer-detective must come back to the elite ring to fight for the champion title once again. According to the plan, this will cause a sensation and lure the robber-boxer in as a spectator. The boxer-major starts training again, gets in the ring, wins his first fights, and this unusual plan works. The hero's final knockout becomes his triumph-the robberboxer has been lured in and arrested. Smart way to use your head, isn't it?

Devotion to the Motherland and the bravery of Soviet athletes is the leitmotif of The Third Half (1962). The film depicts the feat of the Kiev soccer players who reportedly did not agree to lose to the Nazi team, and were eventually shot (the so-called "Death Match"). However, this seems to be the only sports-specific example. Movies such as Yachts at Sea (1955), The Boy with the Skates (1962), The Silver Coach (1963), Long Distance Runner Tactics (1978), and The Invincible (1983) should be attributed to other genres such as adventure, post-war, military, and the Soviet western. Exclusions from the "hero's way" are two films about auto racing, which are non-Olympic practices. These are Speed (1983) and Racers (1975), both without glorious victory in final.

In the last decade, Russian cinema just goes on with Soviet traditions in praising elite sports, and, in some cases, remakes them. However, there are quite a few differences. In Eleven Hopes, the female doctor has a romantic affair with a soccer player, whereas in The Coach (2018), the same situation happens with the trainer. Poddubny (2012) mythologizes only the eponymous champion, although Wrestler and a Clown (1958) had two main characters. The Match (2012) added a love affair to the feats of a soccer player, although a love affair is absent from the Third Half. The First Swallow (1975) smiles romantically over the past, while Garpastum (2008) paints it in more dramatic colors. Rings of Glory (1962), The Right to Jump (1972), and The Invincible (1983) were dedicated to individual athletes whose on-screen incarnations received fictitious names. Today's Streltsov (2020), White Snow (2021), or Legend No. 17 (2013) do not use pseudonyms, but treat historical facts rather loosely. Going Vertical (2017), on the contrary, is much closer to historical reality than The Center from the Skies. However, in general, although the on-screen sportheroes of the last decade are not young blacksmiths or florist girls any longer but only elite athletes, the master narrative of sports cinema remains the same. Champions (2012), Champions: Faster, Higher, Stronger (2016), and the others continue to win, just as they did half a century ago.

The Soviet films mentioned above describe the sphere of elite sport with its training of prospective top champions, include youth level. However, a logical question arises: where is the mass non-elite sport that "aids ordinary citizens to be agile, strong, and healthy"?

\section{Selection № 2: The Non-elite Athletes}

Recreational, non-elite sports are sometimes mentioned in general-theme movies, usually as an episode or as a detail that describes the character's appearance. It is noteworthy 
that sports here are presented in a totally different manner. Unheroic heroes, antiheroes, and antagonists are a notable cohort of on-screen, non-elite athletes. Forced to run is translator Buzykin, the unheroic-hero of the Autumn Marathon (1979). He is a talented but weak person, entangled in romantic affairs, and forced into constant deception. His jogging in the mornings is also a consequence of his spinelessness-he finds it inconvenient to refuse the company of his foreign colleague, who is also a jogger. In the finale, the fit Professor Hansen in his elegant sportswear and the absurdly dressed Buzykin run down the empty morning street.

The music critic Zuev, the antagonist from the melodrama Start All Over Again (1985) also jogs. He is a confirmed retrograde who has no sense of fresh currents in music and the tastes of the youth. We hear of his divorce from reality even in his daughter's remark: "But dad is not here, he is running around the ponds." There he is caught by the protagonist, the rock-singer Kovalev, who persuades Zuev to withdraw his police complaint against a fan girl. "Damned running, after each circle my heart stops and my leg twists" confesses the critic, and eventually gives in to the musician's genteel request.

Within this cohort of non-elite Soviet athletes, one also can find characters "infected with bourgeois morality". A passion for aerobics symbolizes a fashionable life for the "trickster" saleswoman Nadezhda in the lyrical melodrama The Blonde Around the Corner (1984). During the Soviet era, the activities of such heroes were on the verge of economic crimes, which might bring them imprisonment. ${ }^{1}$ Olga, another representative of the economically successful Soviet social strata and the character in the spy television drama TASS is Authorized to Declare . . . (1984), also plays tennis. She is the wife of a Soviet foreign trade official; it was an economically attractive and fancy job in the USSR. The elegant KGB investigator pursues her in his search for a spy, but suddenly the young woman is poisoned by her sports partner who turns out simultaneously to be the wanted CIA agent and her lover.

The production of a comic effect seems to be the main "function" of recreational sports filmed by Soviet cinema. The discrepancy between a royal-majesty suit and a sport-suit is played out in the sci-fi comedy Ivan Vasilievich: Back to the Future (1973). Due to an error in a scientific experiment, the Russian Tsar Ivan IV (Ivan the Terrible) accidentally arrives in Moscow of the 1970s. Thus he, the Grand Duke of Moscow, and all of Rus' is forced to dress in modern clothes. The scene where he enters wearing the "Dynamo" sport club uniform together with his royal regalia (Monomakh's Cap, the royal belt, and scepter) gives rise to a burst of laughter, even among contemporary viewers. Another humorous scene is that of gymnastic exercises in the Soviet adaptation of the comic novel Three Men in a Boat (To Say Nothing of the Dog) (1979). In the original, Jerome K. Jerome described the journey of three thirty-years-olds up the Thames. In the Soviet film, instead of rowing against the current, we see a lazy-rafting down the calm water. The protagonists

1. Critic Gorelov puts on the same list Citizen Koreiko, "a man in his last fit of youth", a secret Soviet millionaire and plunderer of national property, who exercises with dumbbells (2019). However, the comedy The Golden Calf (1968), based on the classic eponymous novel by Ilya Ilf and Evgeny Petrov, describes a different historical era. 
are three 40-year-old burly gentlemen. Their rounded bellies are effectively accentuated by tight-fitting maillots.

The famous song Morning Gymnastics was conceived for the Moscow Satire Theater. The Soviet bard Vladimir Vysotsky wrote it for the comedy play Last Parade (1968). Waking up the morning after, the sailors go to the table with alcoholic drinks "to cure themselves from hangover", but when they hear Morning Gymnastics on the radio, they immediately decide in favor of physical exercises - thus achieving the desired comic effect.

The protagonist of The Blonde Around the Corner (1984) amusingly runs away from his own wedding. A man, in a jacket and tie but no trousers, follows two young joggers out somewhere into the night. The element of buffoonery within the melancholy melodrama Life on Holidays (1980) is the physical-exercise scene together with its organizer. Bouncing and dancing, the elderly animator Lisyutkin takes his equally elderly and bored team out to do some gymnastics. The comic element is underlined by the song played to an accordion tune. This is Count Boni's song from The Gypsy Princess operetta.

A jogging episode from the popular comedy Gentlemen of Fortune (1971) became a well-known satirical sporty meme. A group of criminals escapes from prison. Instead of an empty truck, they find themselves in a tank of liquid cement, their clothes ruined. The gangsters are forced to run in their underwear imitating athletes. At the end of the race in the hotel's lobby, a conversation is started between the "reluctant athletes" and a well-informed sports fan: "What club are you from, comrades?' 'Labor Reserves!' And what about "Dynamo", are they running?' 'Everyone's running."' This phrase has become a widely used joke-it has been said in the wake of usual joggers.

The fitness comedy Seven Old Men and a Girl (1969) requires a detailed description as the only film dedicated to recreational sports. A young but tough girl who has graduated from the Institute of Physical Education gets a job in the Sports Palace. She dreams of training Olympic "princes", anticipating great victories and gold medals. Instead, she is assigned to the so-called "Health group for the middle-aged and elderly people" of

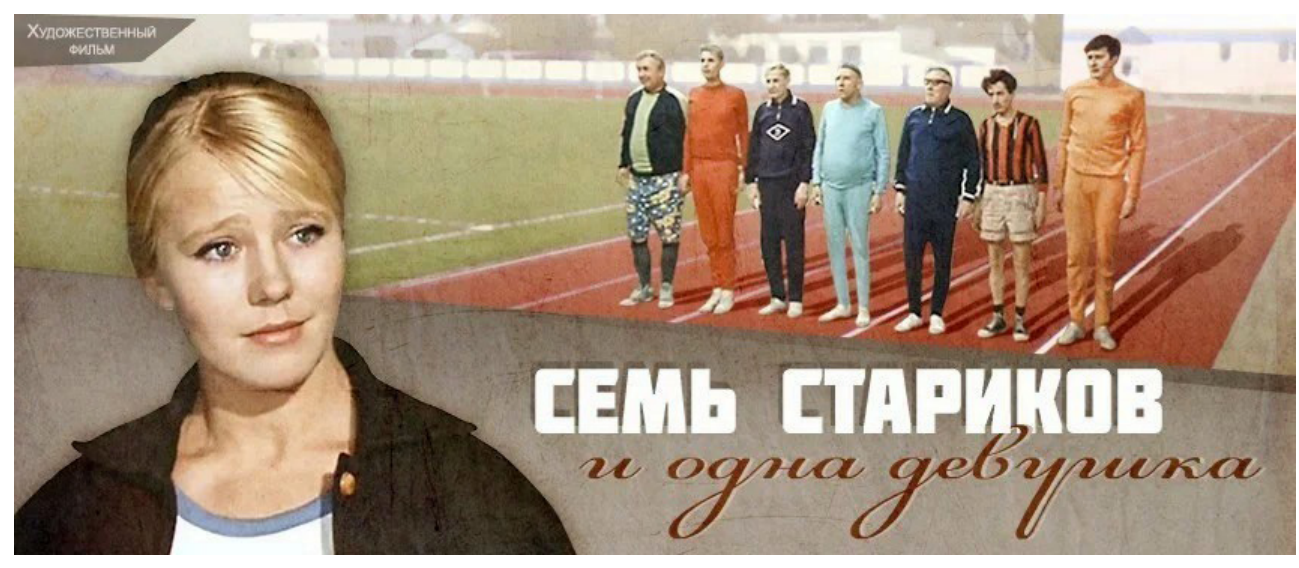

Comical view on Fitness: Seven Old Men and a Girl (1968) 

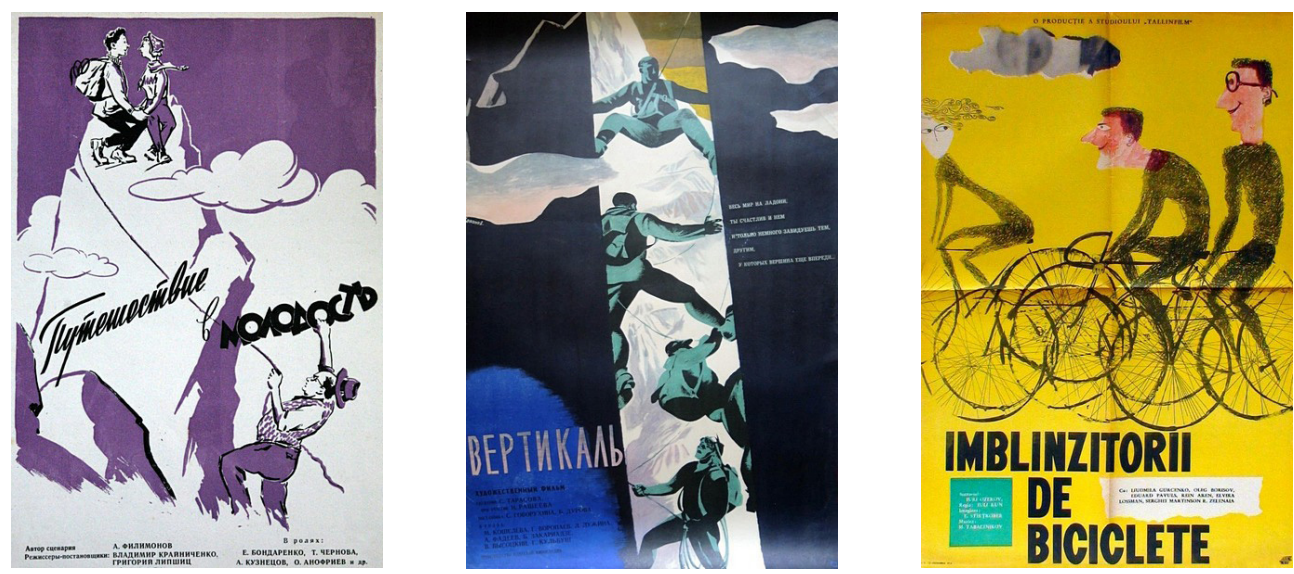

Clear exception from laughing at non-elite amateurs:

Journey to Youth (1956), Vertical (1966), Bicycle Tamers (1968)

seven "old men" in poor physical shape. The belle is annoyed: this is not the material to "forge" Olympic champions. She tries to get rid of the imposed "elders' by any means in order to get a normal coaching job, where she could find a "prince". This is the comedy's opening line, which in its own way reproduces the story \#709 from Aarne-ThompsonUther's fairy tale index. The film itself is close to The Marx Brothers' "absurd comedies", but instead of circus tricks, it demonstrates ridiculous physical exercises performed by old men.

The belle mocks them in every possible way, giving either extremely heavy, or, on the contrary, ridiculously low physical exercise loads. Instead of sports games, the young lady prefers the so-called general physical fitness training: "Madame Elena, shall we play in Russian skittles?' 'No! Let's do toes bouncing. Let's go!' 'The old men don't like this. . . . Women are already playing volleyball, whereas we are just hanging around. This is an insult to the males!"

However, the young lady is adamant and the complaints continue: "It's ridiculous somehow. The women are already swimming in the pool, and we are . . . it does not look nice.' 'But the women are already ... playing water polo!"”

The other guests of the Sports Palace are not friendly, either. After a short dialogue: “"Daddy, please stand up. 'What do you want, sonny?" a teenage-wrestler knocks an elderly man to the ground. "Nice trick", comments another lad approvingly, as the daddy "scrapes" himself off the floor. The upshot is loosely connected to the main plot, but also looks rather grotesque. After the old men have allegedly improved their vitality and gotten stronger after some physical training, they successfully disarm a gang of equally clown-looking robbers in the same vaudeville style.

Exclusions from the tradition depicting non-elite athletes as "clowns" and anti-heroes seem to be few. Noteworthy is the eclectic comedy The Bicycle Tamers (1963), where the three main characters decide to prefer their romantic conquests over ephemeral sport 
glory. The film is the third remake based on the previous two, Dangerous Turns (1960) and Naughty Turns (1959), where the background of the romantic action is not cycling, but motorcycle racing. Another notable exception is the movies depicting non-Olympic practices. These is the drama Fox Hunting (1980) where the hero's hobby is radio sport, as well as the mountaineering dramas Vertical (1966) and While the Mountains Are Standing (1976). The theme of amateur hiking, vocation tourism, and "wild", undeclared outdoor recreation is deployed as a positive background in a number of comedies such as Journey to Youth (1956), Three Plus Two (1963), Sportloto-82 (1982), etc. Moreover, it is a trailhiking experience that is vividly demonstrated as a paradigmatic sport practice for the canonical Soviet "student, Komsomol girl, sportswoman and just a beauty", the protagonist of the famous comedy Kidnapping, Caucasian Style (1967).

\section{Selection № 3: Realities and Criticism of Soviet Sports}

The tiniest category of fictional sports films is those where art sought to reflect the real situation in the Soviet sports industry. The comedy Penalty Kick (1963) criticizes the practices of shamateurism and the weird "double" shamateurism which took root in the USSR. The film's main antagonist is Kukushkin, the sports manager in some rural district. He offers a fee to a group of elite athletes for the performance at the regional Spartakiade, where they should pretend to be the "rural amateur athletes from Petrovsky district". The expected high score of the district team is supposed to earn the manager a promotion. After some bargaining over the pay's size, the elite athletes agree to the fraud. The worldclass hockey player Kovalev becomes "combine operator Semyonov", the top-boxer Sizov turns into "irrigation engineer Dubrov", the prize-winning runner Goncharov is the "specialist in mechanics Kalachev", the speed-skater medalist Kuzin pretends to be "stockbreeder Ptitsyn", whereas the internationally-recognized male gymnast Nikulin becomes "poultry-farm chief Maslyukov". Moreover, the "poultry man" gymnast admits that he "only cared for chickens when they were fried", while the manager Kukushkin is familiar with sports in a similar way. The filmmakers turn the supposed "Spartakiad heroes" into clowns through unexpected plot twists. The eloquent sports manager is offered to take up skiing himself in order to "shake out some fat". An elite gymnast has to ride a horse while a prize-winning runner has to jump off a ski ramp. The result is disastrous: a serious performance turns into a comedy. In the finale, the fraud is exposed, and the manager along with his inglorious "sports heroes" are condemned and ostracized.

The film Male Games in the Open Air (1979) is unusual in a number of aspects. It is a feature movie filmed in a pseudo-documentary manner with non-professional actors in the lead roles. In fact, they play themselves as elite athletes. According to the plot, a group of filmmakers makes a documentary about athletics. It focuses on the already-known duel between the young and the distinguished top-level decathletes, but the heroes do not behave heroically at all. Dirty tricks are used even at the stadium: an accidental discusthrowing directed at an opponent, grabbing his hand while hurdling, etc. No less acute a struggle for economic resources goes outside the stadium at the backstage. It is note- 

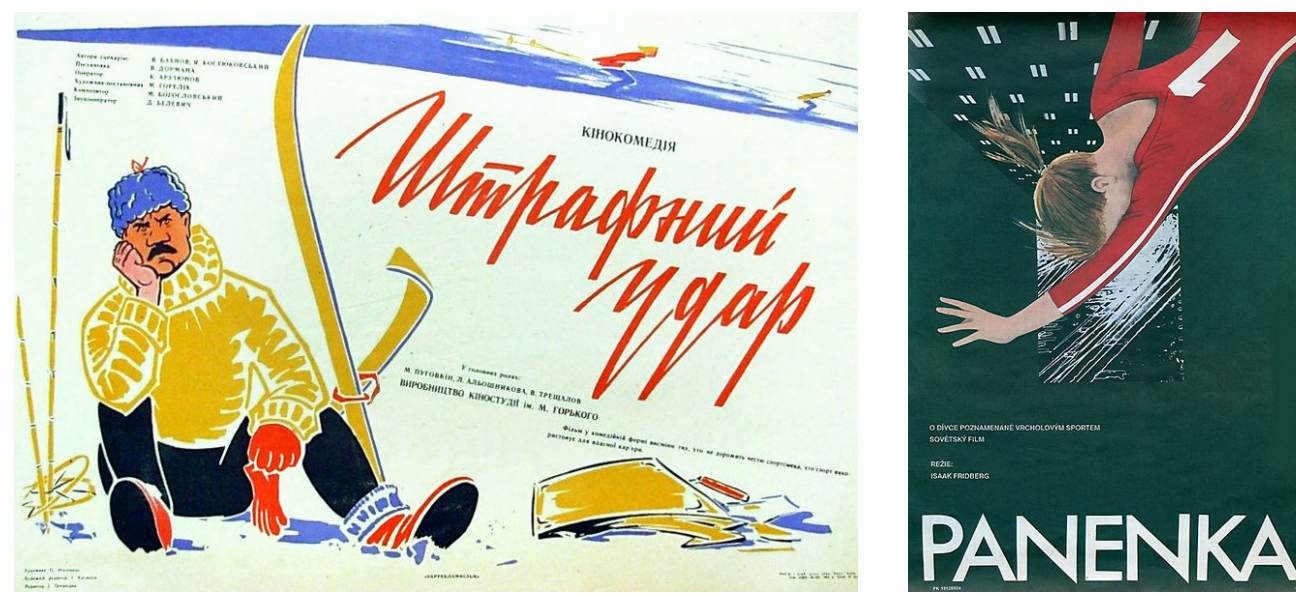

Critical view on Soviet sport: Penalti Kick (1963), A Little Doll (1988)

worthy, that according to Viktor Gruzenkin who played one of the main roles, the film was released in a greatly reduced form. The original script by German Klimov described the life of elite athletes, coaches, and managers in its true colors: heavy alcohol consumption, promiscuity, backstage games, money affairs, smuggling during the foreign trips, etc. However, the film was censored by two thirds of its original length (Kutakov, Gruzenkin, 2012).

The Hockey Players (1962) could have been classified as a typical sports heroic film, if not for two points. It challenges the "natural character" of generational changes, while disputing the sacred thing-the authority of the coach. This character is exposed as an incompetent anti-hero. This conflict of "coach vs. team captain" is reproduced later in Such a Tough Game-Hockey (1983), but with more expurgations. The Second Attempt of Viktor Krokhin (1977) also stands out from this heroic line. The path to victory in the European Championships is not depicted here as a "hero's journey" but as a compromise with one's conscience. It is noteworthy that the film was "laid on a shelf", its release happened only in 1987.

The problem of social adaptation for "sport heroes" was mentioned in the Oscar-winning melodrama Moscow Does Not Believe in Tears (1979). One of the secondary characters at the beginning of the story is the world-famous hockey player Sergei Gurin, an enviable bridegroom and a polite, modest person. Twenty years later, though, he is a devastated drunkard, a barfly regularly wined by his former fans. In the finale, the ex-hockey player seems to give up alcohol and plans to start coaching. According to the film's director, Vladimir Menshov, this open final with a hint at happy ending was imposed by censorship, who decided not to shame the "ex-member of the USSR national team". The removed scene depicts the ex-hero who, having "unleashed the demon", comes to his exwife to ask for three rubles, then the price of a vodka bottle. He is already malty and dusty and is accompanied by some drunkard. The ex-wife kicks out the ex-hero with abuse. His 
companion objects: "How are you talking to him? This is Gurin, I've been grown up on his games!" (Pavlov, 2014). This sports hero Gurin never existed, but he is a generalized character combining many prototypes: "Former soccer stars are on duty at the beer-stalls, asking for a fistful of change, they are well known to local drunkards, who willingly serve them beer and vodka" (1980) (Tolstoy, 2014). Perhaps this description given by journalist Sergei Dovlatov was movie-inspired, but it was an unpleasant truth. The social adaptations problem of the elite athlete is also played up in the drama Lucky (1987), but in a gentler fashion.

The drama film A Little Doll (1988) tells the story of sixteen-years-old ex-world champion (she is also the movie's antihero), who is unable to fit into real life after retiring from elite sport. Her career in gymnastics came to an abrupt end due to an injury. Trying to "be the first" as she was taught in sports, the ex-star does not take either the circumstances or the feelings of other people into account. This only brings her into conflict with those around her. The sad finale refers to the tragic story of Elena Mukhina, a famous gymnast who was disabled at the age of nineteen due to the pressure of her coaches (Tsyrkun, 2007). The message of the film concerns topics unpleasant for sports, such as unjustified injuries, early professionalization, and, de-facto, the exploitation of child labor.

The late-Soviet perception of sport as the sphere of professional occupation is unexpectedly found in the popular comedy film Afonya (1975). Its main character is a thirtyfour-year-old locksmith-plumber from the public service engineering office, Afanasy Borshchev, cheerful by nature, partly a neer do-well, partly a superfluous man. Although he makes good money taking bribes from his clients, his life is pointless. Trying to have fun through alcohol, he periodically gets drunk, gets involved in fights over women, and is even temporarily detained by the police. His co-workers condemn him, though strive to get him back on the right track. The film contains Afanasy's short monologue about sports, inspired by the picture of weightlifter training in a nearby house. It turns out that the hero was once a sub-elite volleyball player, the team captain, saying "I reached the first level [i.e. highest sub-elite]. I was promoted to masters [i.e. national elite]. Now I would be a coach. I would travel abroad. If I hadn't quit."

We believe that this is not the Afanasy's prototype to quit sports. Rather, the sport itself has changed, having rejected the masses of enthusiastic amateurs like Borshchev. Until 1966, the efficiency of the Soviet sports industry's work among grassroots sports teams was assessed by quantitative credit, so sports managers were still interested in real amateurs. Then the grassroots teams began to be evaluated only against the backdrop of the individual top athletes' success. Soviet sport was finally integrated into the global "Olympic order", having ceased to be a "quest for excitements" for the multitude of former amateurs. The film demonstrates, perhaps unwittingly, a kind of inversion of the classic dichotomy of "sports versus alcohol, violence and fights". However, particularly in Afanasy's case, a happy ending was proposed for the final. The pretty nurse Katya, whose brother played on the same team with Afonya, is in love with the hero. Our superfluous man will find a way to salvation if he accepts her love and her proposal: "We can go along the Yenisei River this summer, on a hike.” Well, is this amateur hiking again? 


\section{Mythologizing, Reflecting, Criticizing, Ridiculing?}

Let us summarize and discuss the representations of sports in Soviet cinema that we have distinguished. Most feature sports films of 1950s-1980s construct the "heroic myth". The athlete is portrayed as a model citizen, his trainings are hard work, a manifestation of will, dedication and devotion to the Fatherland in striving for the highest goal. Usually it is about success at international competitions where an elite athlete represents their country. A more modest level is typical only for teenage characters. Portraying the Soviet elite sports system and the Olympic reserve training system in a positive light, these movies depict the desired order, but not the real situation.

The gradual transformation of the Soviet sports cinema genre is noteworthy. In the Stalinist era, the myth of the heroic athlete had been created in the genre of comedy. In the Khrushchev Thaw era, The Hockey Players (1962) became a breakthrough film since it was probably the first time when cinema switched from comedy to drama, actively discussing specific problems within the sports industry. With the rise of the Brezhnev era of stagnation, sports movies progressively took on the features of a stamped cliché. One can find a very illustrative scene in the Challenge (1986), where the female protagonist, a fencer, with a casual poignancy tells her friend the story of her awards: "Medal for labor, medal for pain ... medal for the coach's heart." Elite sports are shown as a kind of a standard-feat reproduction, and the sports movie genre itself acquires the industrial dramatic features (as with firefighters, rescue workers, doctors, etc.).

The portrait drawn of the "heroic athlete" turned out to be quite different from the model. The real costs of "sports heroes" production (the early professionalization, social exclusion, etc.) negatively affected their education, upbringing, and cultural intelligence. The glorification of the "military feat" performed by elite athletes was also controversial. The so-called "Death Match", though artistically famed, proved to be mere literary fiction.

It is also noteworthy that the overall quality of the cultural product being made (sports feature films) was not too high. If more than thirteen sports films were among the ones with highest box-office before 1966, only a few achieved later screen success. Among them were the Seven Old Men ... comedy, and only three "hero-athletic" movies of mixed genres: the musical Center from the Skies ..., the detective story The Ring, and the Soviet western The Invincible. We believe that the filmmaker Maryamov was correct in stating the following in 1986: "Both sports and films of it are experiencing today an acute shortage of viewers". He saw the reasons for this in the lack of intrigue in stadiums, the stereotypical nature of sports cinema, and the inherent flaws of the genre. He considered the film Sport, Sport, Sport (1970), where a talented selection of documentary episodes was sided with "far-fetched" fictional inserts, to be a relative success (1986). His opinion supports the view of elite professional sports as a subspecies of art well-known in academic circles (Stolyarov, 1997). In general, we believe that the Soviet sports cinema of the 1970s-1980 had already served, in social terms, as a means of the stereotypical positive representation of elite sports in public opinion. We believe that such an artistic image of sport actively contributed to the creation of the "evangelical myth" about the motivating 
role of elite sport. A number of recent works have been devoted to its debunking, such as Gleyse et al. (2001), Payne, et al. (2003), Grix, Carmichael (2012), Weed, et al. (2015), and Seguí-Urbaneja et al. (2020).

Attempts to critically reflect on the realities of Soviet sports were relatively small in the total array of film production. Key examples here are the comedy Penalty Kick (1963), where shamateurism is ridiculed, or A Little Doll (1988), the drama of social alienation of ex-elite athletes. It should be noted that these movies were filmed during the Khrushchev Thaw and Gorbachev's Perestroika. Others films, challenging the positive image of "sports heroes", such as Male Games in the Open Air (1979), were heavily censored.

Since the late 1960s, recreational, non-elite sport in Soviet cinema, as it may seem, is either predominantly represented in the comic sense, or complements the images of antagonistic characters. We are talking of the unique example of the fitness-comedy Seven Old Men and a Girl (1966), but also of many characteristic episodes in general-theme films. The obvious question here is what is the reason for this artistic reflection? Explaining the clown-looking fitness episodes in late Soviet movies, the film critic Denis Gorelov believes that "by the 1970s, physical culture, like any noble cause, promoted in the topdown manner, had finally discredited itself" (2019). A similar opinion was previously expressed by Mike O'Mahony (in the Russian edition of his book): "In the Stalinist era, the physical culture was taken as a very serious theme, while in the 1970s-1980s ... depicting physical culture and sports meant political and ideological conformism" (2010: 27).

Discussing the topic of Soviet sports cinema, we would like to challenge this view. In fact, the Soviet sports industry underwent a gigantic transformation from the 1940s to the 1960s. Western researchers have noticed a significant change in the goals of Soviet sports policy. However, it does not mean the factual disappearance of genuine (competitive) mass sport. Soviet sport industry insiders (Anatoly Isaev, Pyotr Vinogradov, and many others) observed, in their turn, the confidential situations from within also being directly involved in critical discussions. The director and screenwriter of Seven Old Men . .., Evgeny Karelov, was also a sports industry insider, having graduated from the Sports Institute and initially planning to work as a coach.

We think that the comedy trick of throwing of an old man to the ground by a teenager athlete may serve an obvious allegory for the shaking-out of genuine sports heroes of the 1920s-1930s, which finally took place in 1966 due to "Olympic" changes in the system of work with sports at the grassroots level. "Bouncing on toes" instead of sports games is a clear allegory of the well-known thesis of sports significance, which was voiced by the Soviet health minister Nikolai Semashko in 1927. Physical exercises "for the sake of health" were considered pointless, but health was an industry goal, achieved through the mass sport involvement. The "Malt o'meal of hygienic gymnastics" proposed instead of sports looked really ridiculous. The criticism of Penalty Kick as pathetic does not require any explanation. The scriptwriter was Yakov Kostyukovsky, a professional ironist and well-known connoisseur of Soviet sports, as well as a big fan of the Central Army Sports Club (CSKA) since 1937. German Klimov was also an industry insider: the screenwriter 
of Sports, Sports, Sports and Male Games ... was initially an elite decathlete. The famous weightlifter Yuri Vlasov, a rigorous critic of the industry, needs no special introduction.

The portrayal of individual non-elite amateurs as "infected with bourgeois morality" probably reflected the usual economic inaccessibility of recreational sports in the lateSoviet period. At the same time, Soviet cinema portrayed the practice of mountaineering and off-trail hiking positively. These activities, however, were autonomously organized and almost independent of the official sports industry. Thus, the ironic representation of non-elite sport by artistic means is difficult to reduce to a common denominator.

\section{In fine}

In summary, we may propose the following conclusions. Since the late 1960s, Soviet sports cinema was no longer a propagandist tool for promoting a healthy lifestyle and recreational sporting activity for non-elite amateurs (if we exclude amateur hiking practices). At the same time, the top sport (which is itself an art form) as well as its artistic representation, as if two arms acting together, constructed the great "evangelical" myth of elite sports, which became a part of the public consciousness. However, this myth had little to do with the reality transformed during the second half of the twentieth century. The art, creating a hero out of an elite athlete, was not reflecting reality any longer, but acted as a propagandist tool on behalf of the "Olympic ideology", creating fictional social worlds. The existing social order's irrationality was critically reflected only in the comedy genre.

Note that the satirical exposure of "certain shortcomings" in the USSR was a permitted form of social criticism. A typical example thereof is the Soviet satirical magazine Crocodile, which has devoted many cartoons to "sports heroes". It ridiculed the attitude of sports managers to elite athletes as a scarce resource, educational problems among "sports heroes", etc. Thus, it is not a question of "non-conformism", or of a "complete decline of previously existed values in society as a whole", or of "physical culture [that] finally discredited itself". It concerns the obvious criticism of the social order in a specific area of public life, which changed its course by 180 degrees in favor of "glorious Olympic goals". However, the array of Soviet sports films studied in our paper outlines the contours of a solid propaganda for grassroots sports to some degree. The Hero should dramatically climb the mountain (run a marathon, a triathlon, etc.), or prefer a romantic victory over the sporty one.

\section{Appendix}

\section{Soviet fiction movies based on Olympics sports}

1936. The Goalkeeper. [Russ.: Вратарь]. Dir.: Tymoshenko Semyon. Writ.: Kassil Lev, Yudin Mikhail. Stud.: Lenfilm. Sport: soccer.

1946. The First Glove. [Russ.: Первая перчатка]. Dir.: Frolov Andrey. Writ.: Filimonov Alexander. Stud.: Mosfilm. Sport: boxing. 
1947. Center Forward. [Russ.: Центр нападения]. Dir.: Derevian Semyon, Zemgano Igor.

Writ.: Laskin Boris, Pomeshchikov Evgeny. Stud.: Dovzhenko Film. Sport: soccer.

1951. Sporting Honor. [Russ.: Спортивная честь]. Dir.: Petrov Vladimir. Writ.: Volpin

Mikhail, Erdman Nikolay. Stud.: Mosfilm. Sport: soccer.

1954. The Reserve Player. [Russ.: Запасной игрок]. Dir.: Tymoshenko Semyon. Writ.:

Tymoshenko Semyon. Stud.: Lenfilm. Sport: soccer.

1954. World Champion. [Russ.: Чемпион мира]. Dir.: Gonchukov Vladimir. Writ.: Ezhov

Valentin, Soloviev Vasily. Stud.: Gorky Film. Sport: classic wrestling.

1955. Yachts at Sea. [Russ.: Яхты в море]. Dir.: Egorov Mikhail. Writ.: Vasiliev Arkady,

Likhobabin Nikita. Stud.: Tallinnfilm. Sport: yachting.

1958. Wrestler and a Clown. [Russ.: Борец и клоун]. Dir.: Barnet Boris, Yudin Konstan-

tin. Writ.: Pogodin (Stukalov) Nikolay. Stud.: Mosfilm. Sport: classic wrestling.

1960. The Winner. [Russ.: Победитель]. Dir.: Sadovsky Victor. Writ.: Nagibin Yuri. Stud.:

Lenfilm. Sport: speed skating.

1962. The Third Half. [Russ.: Третий тайм]. Dir.: Karelov Evgeniy. Writ.: Borschagovsky

Alexander. Stud.: Mosfilm. Sport: soccer.

1962. Rings of Glory. [Russ.: Кольца славы]. Dir.: Yuri Yerzinkyan. Writ.: Filimonov Al-

exander, Kocharyan Yakov. Stud.: Armenfilm. Sport: artictis gymnastics.

1963. The Silver Coach. [Russ.: Серебряный тренер]. Dir.: Ivchenko Victor. Writ.: Kush-

nirenko Georgy. Stud.: Dovzhenko Film. Sport: artictic gymnastics.

1963. Penalty Kick. [Russ.: Штрафной удар]. Dir.: Dorman Benjamin. Writ.: Bakhnov

Vladlen, Kostyukovsky Yakov. Stud.: Gorky Film. Sport: few olympic sports.

1963. Individual Championship. [Russ.: Личное первенство]. Dir.: Skachko Elena. Writ.:

Nagibin Yuri. Stud.: Mosfilm. Sport: boxing.

1964. Strict Game. [Russ.: Строгая игра]. Dir.: Lipshits Grigory. Writ.: Pomeshchikov

Evgeny. Stud.: Dovzhenko Film. Sport: soccer.

1964. The Hockey Players. [Russ.: Хоккеисты]. Dir.: Goldin Raphael. Writ.: Trifonov

Yuri. Stud.: Mosfilm. Sport: hockey.

1964. Lost Summer. [Russ.: Пропало лето]. Dir.: Bykov Roland, Orlov Nikita. Writ.:

Zach Abner, Kuznetsov Isay. Stud.: Mosfilm. Sport: cycling.

1964. Bicycle Tamers. [Russ.: Укротители велосипедов]. Dir.: Kuhn Julius. Writ.: Kuhn

Julius, Ozerov Yuri, Erdman Nikolay. Stud.: Tallinnfilm. Sport: cycling.

1966. A Royal Regatta. [Russ.: Королевская регата]. Dir.: Chulyukin Yuri. Writ.: Vasiliev

Boris, Rapoport Kirill, Sheets Semyon. Stud.: Mosfilm. Sport: rowing.

1968. Kick! Another kick!. [Russ.: Удар! Ещё удар!]. Dir.: Sadovsky Victor. Writ.: Kassil

Lev, Sadovsky Victor, Kunin Vladimir. Stud.: Lenfilm. Sport: soccer.

1968. The New Girl. [Russ.: Новенькая]. Dir.: Lyubimov Pavel. Writ.: Lyubimov Pavel,

Tokarev Stanislav. Stud.: Gorky Film. Sport: artictic gymnastics.

1969. The Coach. [Russ.: Tренер]. Dir.: Bazelyan Yakov. Writ.: Lapshin Alexander. Stud.:

Gorky Film. Sport: artictic gymnastics.

1969. Blue Ice. [Russ.: Голубой лёд]. Dir.: Sokolov Victor. Writ.: Nagibin Yuri, Solodar

Caesar. Stud.: Lenfilm. Sport: figure skating. 
1970. Sport, Sport, Sport. [Russ.: Спорт, спорт, спорт]. Dir.: Klimov Elem. Writ.: Klimov German. Stud.: Mosfilm. Sport: few olympic sports.

1971. Fast Seconds' Cost. [Russ.: Цена быстрых секунд]. Dir.: Chebotarev Vladimir.

Writ.: Chebotarev Vladimir, Smirnov Edgar, Yusin Anatoly. Stud.: Mosfilm. Sport: speed skating.

1971. Tigers on Ice. [Russ.: Тигры на льду]. Dir.: Kozachkov Valentin, Osipov Albert.

Writ.: Merezhko Victor, Gorbunov Nikolay. Stud.: Odessa Film. Sport: hockey.

1971. White Queen's Move. [Russ.: Ход белой королевы]. Dir.: Sadovsky Victor. Writ.:

Kassil Lev, Sadovsky Victor. Stud.: Lenfilm. Sport: cross-country skiing.

1972. Light Water. [Russ.: Легкая вода]. Dir.: Vinnik Vyacheslav. Writ.: Rizin Leonid.

Stud.: Odessa Film. Sport: rowing.

1972. Right to Jump. [Russ.: Право на прыжок]. Dir.: Kremnev Valery. Writ.: Lapshin

Alexander, Brumel Valery. Stud.: Mosfilm. Sport: athletics.

1973. The Large Hill. [Russ.: Большой трамплин]. Dir.: Martynyuk Leonid. Writ.:

Braslavsky Leonid. Stud.: Belarusfilm. Sport: ski jumping.

1973. The Ring [Russ.: Ринг]. Dir.: Novak Villen. Writ.: Leonov Nikolay. Stud.: Odessa Film. Sport: boxing.

1974. Miracle with Pigtails. [Russ.: Чудо с косичками]. Dir.: Titov Victor. Writ.: Lapshin Alexander. Stud.: Mosfilm / Belarusfilm. Sport: artictic gymnastics.

1974. The Lot. [Russ.: Жребий]. Dir.: Voznesensky Igor. Writ.: Maryamov Alexander, Ni-

lin Alexander. Stud.: Gorky Film. Sport: hockey.

1975. The First Swallow. [Russ.: Первая ласточка]. Dir.: Mchedlidze Nana. Writ.: Cheli-

dze Levan, Mchedlidze Nana. Stud.: Georgian Film. Sport: soccer.

1975. Such a Game. [Russ.: Такая она игра]. Dir.: Popkov Vladimir, Maletsky Nikolay.

Writ.: Vinnik Vyacheslav, Tokarev Stanislav. Stud.: Dovzhenko Film. Sport: soccer.

1975. Vocation. [Russ.: Призвание]. Dir.: Baltrushaitis August. Writ.: Mashkin V., Egorov

S.. Stud.: Lenfilm. Sport: cycling.

1975. The Center from the Skies. [Russ.: Центровой из поднебесья]. Dir.: Magiton Isaac.

Writ.: Aksyonov Vasily. Stud.: Gorky Film. Sport: basketball.

1976. Eleven Hopes. [Russ.: Одиннадцать надежд]. Dir.: Sadovsky Victor. Writ.: Ezhov

Valentin, Sadovsky Victor. Stud.: Lenfilm. Sport: soccer.

1977. Moment of Luck. [Russ.: Миг удачи]. Dir.: Plotkin Vsevolod. Writ.: Priemykhov

Valery. Stud.: Sverdlovsk Film. Sport: downhill skiing.

1977. The Second Attempt of Viktor Krokhin. [Russ.: Вторая попытка Виктора Крохина].

Dir.: Sheshukov Igor. Writ.: Volodarsky Edward. Stud.: Lenfilm. Sport: boxing. 1978. It's a Moment. [Russ.: Всё решает мгновение]. Dir.: Sadovsky Victor. Writ.: Ezhov

Valentin, Sadovsky Victor. Stud.: Lenfilm. Sport: swimming.

1978. Long Distance Running Tactics. [Russ.: Тактика бега на длинную дистанцию].

Dir.: Vasiliev Evgeniy, Fruntov Rudolph. Writ.: Klimov German. Stud.: Mosfilm. Sport: athletics. 
1978. Male Games in the Open Air. [Russ.: Мужские игры на свежем воздухе]. Dir.: Kalninsh Roland, Piesis Gunar. Writ.: Klimov German. Stud.: Riga Film. Sport: athletics.

1979. Iron Games. [Russ.: Железные игры]. Dir.: Martynyuk Leonid. Writ.: Kunin Vladimir. Stud.: Belarusfilm. Sport: weightlifting.

1980. Faster than Your Own Shadow. [Russ.: Быстрее собственной тени]. Dir.: Lyubimov Pavel. Writ.: Orlov Dal. Stud.: Gorky Film. Sport: athletics.

1981. At the Beginning of Game. [Russ.: В начале игры]. Dir.: Mastyugin Yuri. Writ.: Stepanov Anatoly. Stud.: Gorky Film. Sport: soccer.

1981. The Girl and Grand. [Russ.: Девушка и Гранд]. Dir.: Sadovsky Victor. Writ.: Ezhov Valentin, Sadovsky Victor. Stud.: Lenfilm. Sport: equestrianism. 1982. Eighth Wonder of the World. [Russ.: Восьмое чудо света]. Dir.: Samsonov Samson.

Writ.: Kapitanovsky Vladimir. Stud.: Mosfilm. Sport: basketball. 1984. And a Beautiful Moment of Victory. [Russ.: И прекрасный миг победы]. Dir.: Vinnik Vyacheslav. Writ.: Vinnik Vyacheslav. Stud.: Dovzhenko Film. Sport: handball. 1985. Rivals. [Russ.: Соперницы]. Dir.: Sadovsky Victor. Writ.: Ezhov Valentin, Sadovsky Victor. Stud.: Lenfilm. Sport: rowing.

1986. Challenge. [Russ.: Вызов]. Dir.: Kolovsky Igor. Writ.: Antipova Faina, Milova Eleonora. Stud.: Belarusfilm. Sport: fencing.

1987. Lucky. [Russ.: Везучая]. Dir.: Shukher Oleg. Writ.: Slutsky Ganna. Stud.: Mosfilm. Sport: athletics.

1988. A Little Doll. [Russ.: Куколка]. Dir.: Friedberg Isaac. Writ.: Ageev Igor. Stud.: Mosfilm. Sport: artictis gymnastics.

\section{Soviet fiction movies based on Alpinism/Hiking, Fitness, Martial arts, Military- technical}

1940. The Old Rider. [Russ.: Старый наездник]. Dir.: Barnet Boris. Writ.: Volpin Mikhail, Erdman Nikolay. Stud.: Mosfilm. Sport: horse racing.

1956. Journey to Youth. [Russ.: Путешествие в молодость]. Dir.: Kraynichenko Vladimir, Lipshits Grigory. Writ.: Filimonov Alexander. Stud.: Dovzhenko Film. Sport: mountaineering.

1960. Dangerous Turns. [Russ.: Озорные повороты]. Dir.: Kiisk Kalyo, Kun Julius. Writ.:

Normet Dagmar, Stern Sandor. Stud.: Tallinnfilm. Sport: motorcycle racing. 1961. Naughty Turns. [Russ.: Опасные повороты]. Dir.: Kiisk Kalyo, Kun Julius. Writ.: Normet Dagmar, Stern Sandor. Stud.: Tallinnfilm. Sport: motorcycle racing. 1966. Vertical. [Russ.: Вертикаль]. Dir.: Govorukhin Stanislav, Durov Boris. Writ.: Tarasov Sergey, Rasheev Nikolay. Stud.: Odessa Film. Sport: mountaineering. 1968. Seven Old Men and a Girl. [Russ.: Семь стариков и одна девушка ]. Dir.: Karelov Evgeniy. Writ.: Karelov Evgeniy, Ivanov Albert. Stud.: Mosfilm. Sport: recreational fitness.

1972. Racers [Russ.: Гонщики]. Dir.: Maslennikov Igor. Writ.: Olshansky Iosif, Rudneva Nina, Maslennikov Igor. Stud.: Lenfilm. Sport: auto racing. 
1976. While the Mountains are Standing. [Russ.: Пока стоят горы]. Dir.: Mikhailov Vadim. Writ.: Mikhailov Vadim, Shulgina Albina. Stud.: Lenfilm. Sport: mountaineering. 1980. Fox Hunting. [Russ.: Охота на лис]. Dir.: Abdrashitov Vadim. Writ.: Mindadze Alexander. Stud.: Mosfilm. Sport: radio sports.

1983. Speed. [Russ.: Скорость]. Dir.: Dmitry Svetozarov. Writ.: Zvereva Maria. Stud.:

Lenfilm. Sport: auto racing.

1983. The Invincible. [Russ.: Непобедимый]. Dir.: Boretsky Yuri. Writ.: Lungin Pavel.

Stud.: Gorky Film. Sport: martial arts.

\section{Selected Soviet films containing scenes of Sports and Fitness (mostly box-office)}

1962. The Boy with the Skates. [Russ.: Мальчик с коньками]. Dir.: Gippius Sergey. Writ.:

Yakovlev Yuri. Stud.: Lenfilm. Sport: recreational fitness. (Note: wrongly attributed as a Sports film by Zlodoreva).

1963. Three Plus Two. [Russ.: Три плюс два]. Dir.: Hovhannisyan Henrikh. Writ.: Mikhalkov Sergey. Stud.: Gorky Film / Riga Film. Sport: tourism.

1967. Kidnapping, Caucasian Style. [Russ.: Кавказская пленница]. Dir.: Gaidai Leonid. Writ.: Kostyukovsky Yakov, Slobodskoy Maurice, Gaidai Leonid. Stud.: Mosfilm. Sport: hiking.

1968. The Golden Calf. [Russ.: Золотой телёнок]. Dir.: Schweitzer Mikhail. Writ.: Schweitzer Mikhail (based on novell by Ilf Ilya and Petrov Eugeny). Stud.: Mosfilm. Sport: fitness / weightlifting.

1968. Last Parade. [Russ.: Последний парад]. Dir.: Pluchek Valentin. Writ.: Stein Alexander. Stud.: Moscow Satire Theatre. Sport: fitness. (Note: theatre play). 1971. Gentlemen of Fortune. [Russ.: Джентльмены удачи]. Dir.: Gray Alexander. Writ.:

Danelia Georgy, Tokareva Victoria. Stud.: Mosfilm. Sport: jogging. 1973. Ivan Vasilievich: Back to the Future. [Russ.: Иван Васильевич меняет профессию]. Dir.: Gaidai Leonid. Writ.: Bakhnov Vladlen, Gaidai Leonid. Stud.: Mosfilm. Sport: fitness.

1975. Afonya. [Russ.: Афоня]. Dir.: Danelia Georgy. Writ.: Borodyansky Alexander. Stud.: Mosfilm. Sport: volleyball.

1979. Three Men in a Boat (To Say Nothing of the Dog). [Russ.: Трое в лодке не считая собаки]. Dir.: Birman Naum. Writ.: Lungin Semyon. Stud.: Lenfilm. Sport: fitness. 1979. Autumn Marathon. [Russ.: Осенний марафон]. Dir.: Danelia Georgy. Writ.: Volodin Alexander. Stud.: Mosfilm. Sport: jogging. 1979. Moscow Does Not Believe in Tears. [Russ.: Москва слезам не верит]. Dir.: Menshov Vladimir. Writ.: Chernykh Valentin. Stud.: Mosfilm. Sport: hockey. 1980. Life on Holidays. [Russ.: Из жизни отдыхающих]. Dir.: Gubenko Nikolay. Writ.: Gubenko Nikolay. Stud.: Mosfilm. Sport: fitness.

1982. Sportloto-82. [Russ.: Спортлото-82]. Dir.: Gaidai Leonid. Writ.: Bakhnov Vladlen, Gaidai Leonid. Stud.: Mosfilm. Sport: tourism.

1984. TASS is Authorized to Declare.... [Russ.: TACC уполномочен заявить ...]. Dir.: Fokin Vladimir. Writ.: Semyonov Julian. Stud.: Gorky Film. Sport: tennis. (Note: TV). 
1984. The Blonde Around the Corner. [Russ.: Блондинка за углом]. Dir.: Bortko Vladimir. Writ.: Chervinsky Alexander. Stud.: Lenfilm. Sport: fitness / jogging.

1985. Start All Over Again. [Russ.: Начни сначала]. Dir.: Stefanovich Alexander. Writ.: Borodyansky Alexander, Stefanovich Alexander. Stud.: Mosfilm. Sport: jogging.

For reasons of brevity, the article does not mention few films, which related to Selection № 1. There are Fast Seconds' Cost (1971), Eighth Wonder of the World (1982), And a Beautiful Moment of Victory (1984), etc.

Source of posters: http://www.kinopoisk.ru/posters/

\section{References}

Adelfinsky A., Anashvili V. (2018) Sport. Russia: Strategy, Policy and Administration (ed. I. Studin), London: Palgrave Macmillan, pp. 295-306.

Adelfinsky A. (2018) Nazlo rekordam: opyt issledovanija massovogo sporta [Despite the Records: An Inquiry into Mass Participation Sports], Moscow: Delo. (In Russian)

Apostolov A. (2014a) Passivnaja passionarnost': zritel' i media v otechestvennyh fil'mah o hokkee [Passive Passionarity: The Spectator and the Media in Russian Movies on Hockey]. Logos, no 6, pp. 149-178. (In Russian)

Apostolov A. (2014b) The Enemy at the Gate: The Soviet Goalkeeper in Cinema, Culture and Policy. Studies in Russian and Soviet Cinema, vol. 8, no 3, pp. 200-217.

Averkova A. (2011) Sport na jekrane: telerezhissura massovogo zrelishha [Sports on the Screen: Television Direction of a Mass Spectacle] (PhD Thesis), Moscow: IPK. (In Russian)

Bonnet V. (2017) Sport in Films: Symbolism versus Verismo. A France-United States Comparative Analysis. InMedia, no 6. Available at: http://journals.openedition.org/ inmedia/883 (accessed 29 December 2020).

Fedorov A. (2018) The Soviet Art House Cinema about the War: Case Study. Journal of International Network Center for Fundamental and Applied Research, vol. 5, no 1, art. 3E9. Available at: http://ejournal36.com/journals_n/1545041534.pdf (accessed 29 December 2020).

Fedorov A. (2020) Leaders of Soviet Film Distribution (1930-1991): Trends and Patterns. Media Education, vol. 60, no 1, pp. 24-62.

Fedorov A. (2021) Tysjacha i odin samyj kassovyj sovetskij fil'm: mnenija kinokritikov $i$ zritelej [A Thousand and One Highest-Grossing Soviet Films: Opinions of Film Critics and Viewers], Moscow: Information for all. (In Russian)

Dennis M., Grix J. (2012) The East German Model in Comparative Context. Sport under Communism: Global Culture and Sport (eds. M. Dennis, J. Grix), London: Palgrave Macmillan, pp. 171-186.

Dufraisse S. (2019) Les héros du sport: une histoire des champions soviétiques (années 19301980), Seyssel: Champvallon. 
Edelman R. (2007) Review: Sport in the USSR: Physical Culture-Visual Culture. By Mike O’Mahony, 2006. Slavic Review, vol. 66, no 3, pp. 558-559.

Fisheva A. (2020) Obraz "novogo cheloveka" v sovetskom kinematografe v 1930-e gg. [The Image of the "New Man" in Soviet Cinema in the 1930s]. Bulletin of the Orenburg State Pedagogical University, no 1, pp. 144-157. (In Russian)

Gleyse J., Jorand D., Garcia C. (2001) Mystique de "gauche" et mystique de "droite" en pédagogie sportive en France sous la Troisième république. Stadion, no 27, pp. 125-137.

Gorelov D. (2019) Vse begut: istorija fizkul'tury i massovogo sporta v sovetskom kino [Everybody Runs: The History of Physical Education and Mass Sports in Soviet Cinema]. Men's Health (Russian Edition), no 8. (In Russian)

Gori G. (2020) Sporting Propaganda in Visual Arts Under the Fascist Regime and the Example of the 1941 Cremona Prize. Sportgeschichte in Deutschland-Sport History in Germany (eds. M. Krüger, A. Hofmann), Wiesbaden: Springer, pp. 53-73.

Grix J., Carmichael F. (2012) Why do Governments Invest in Elite Sport? A Polemic. International Journal of Sport Policy and Politics, vol. 4, no 1, pp. 73-90.

Haynes J. (2007) Film as Political Football: The Goalkeeper (1936). Studies in Russian and Soviet Cinema, vol. 1, no 3, pp. 283-297.

Isaev E., Pozhidaeva I. (2016) Populjarnaja istorija v sovremennoj Rossii: mify, obrazy i predstavlenija o proshlom $\mathrm{v}$ sportivnom istoricheskom fil'me [Popular History in Modern Russia: Myths, Images and Ideas of the Past in Sport Historical Film]. Humanitarian Vector. Series: Philosophy. Cultural Studies, vol. 11, no 4, pp. 128-136. (In Russian)

Katzer N. (2018) Sport kak ideal'nyj social'nyj porjadok: k voprosu o sovetskoj koncepcii fizicheskoj kul'tury [Sport as an Ideal Social Order: On the Question of Soviet Concept of Physical Culture]. Sociology of Power, vol. 30, no 2, pp. 206-230. (In Russian)

Kedrov M.S. (1928) Za fizkul'turnuju samokritiku: ob urodlivyh javlenijah v sovetskom fizkul'turnom dvizhenii i ih prichinah [For Physical Culture's Self-criticism: On Ugly Phenomena in the Soviet Physical Culture Movement and Their Causes]. Teoria $i$ praktika fizicheskoy kultury, no 6, p. 6-12. (In Russian)

Kildyushov O. (2016) Problema social'nogo porjadka (Gobbsova problema): k jevristike i pragmatike konstitutivnogo voprosa sovremennoj teorii obshhestva [The Problem of Social Order (a Hobbesian Problem): Towards the Heuristics and Pragmatics of the Constitutive Question of Contemporary Social Theory]. Russian Sociological Review, vol. 15, no 3, pp. 122-149.

Krüger M. (2014) The German Workers' Sport Movement between Socialism, Workers' Culture, Middle-Class Gymnastics and Sport for All. International Journal of the History of Sport, vol. 31, no 9, pp. 1098-1117.

Kutakov E., Gruzenkin V. (2012) “Esli by ne sport, ja stal by ugolovnikom” (interv’ju) ["If not for sports, I would have become a criminal" (Interview)]. Redyarsk.ru. Available at: https://www.redyarsk.ru/articles/detail.php?id=4316 (accessed 29 December 2020). (In Russian) 
Ligostaeva N. (2018) Obraz sportsmena v hudozhestvennom prostranstve otechestvennogo kinematografa XX-XXI vekov: funkcii i smysly [The Image of the Sportsman in the Art Space of Russian Cinema of the 2oth-21st Centuries: Functions and Meanings]. Aspirantskiy Vestnik Povolzhiya, no 3-4, pp. 53-56. (In Russian)

Llewellyn M. P., Gleaves J. (2012) The Rise of the "Shamateur": The International Olympic Committee and the Preservation of the Amateur Ideal. Problems, Possibilities, Promising Practices: Critical Dialogues on the Olympic and Paralympic Games: Eleventh International Symposium for Olympic Research (eds. J. Forsyth, M. K. Heine), London: International Centre for Olympic Studies, pp. 23-28.

Maryamov A. (1986). Kakova zhe sportivnaja zhizn'? [What is Sports Life Like?]. Sovetskaya kultura, December 9. (In Russian)

O’Mahony M. (2006) Sport in the USSR: Physical Culture-Visual Culture, London: Reaktion Books.

O'Mahony M. (2010) Sport v SSSR: fizicheskaja kul'tura-vizual'naja kul'tura [Sport in the USSR: Physical Culture-Visual Culture], Moscow: New Literary Observer. (In Russian)

Padunov V. (2007) Review: Sport in the USSR: Physical Culture: Visual Culture. By Mike O’Mahony, 2006. Slavic and East European Journal, vol. 51, no 3, pp. 649-650.

Padunov V. (2011) Kak my otkryvali rossijskoe kino [How did We Discover Russian Cinema]. Iskusstvo kino, no. 4. (In Russian)

Pavlov E. (2014) 10 istorij o tom, kak snimali "Moskva slezam ne verit" [10 Stories about Filming Moscow Does Not Believe in Tears]. Rossiyskaya Gazeta, 10.02.2014. (In Russian)

Payne W., Reynolds M., Brown S., Fleming A. (2003) Sports Role Models and Their Impact on Participation in Physical Activity: A Literature Review. School of Human Movement and Sport Sciencies, University of Ballarat.

Physick R. (2017) The Olimpiada Popular: Barcelona 1936, Sport and Politics in an Age of War, Dictatorship and Revolution. Sport in History, vol. 37, no 1, pp. 51-75.

Seguí-Urbaneja J., Inglés E., Alcaraz S., De Bosscher V. (2020) Sport Pyramid Metaphor: Trickle Down and Up Effect in Spain. Revista Internacional de Medicina y Ciencias de la Actividad Física y el Deporte, vol. 20, no 77, pp. 1-20.

Stolyarov V. (1997) Sport i iskusstvo: shodstvo, razlichie, puti integracii [Sport and Art: Similarity, Difference, Ways of Integration]. Sport, duhovnye cennosti, kul'tura. Vyp. 5 [Sport, Spiritual Values, Culture, Issue 5], Moscow: SpArt, pp. 101-265. (In Russian)

Strożek P. (2018) Worker Sport and Art for Proletarian Masses: Constructivist AvantGardes, Spartakiads, and Red Sport International, 1921-1928. International Journal of the History of Sport, vol. 35, no 17-18, pp. 1723-1747.

Tolstoy I. (2014) Chas Dovlatova: Rannie vystuplenija pisatelja u mikrofona Svobody (nachalo 198oh) [Dovlatov's Hour: Writer's Early Speeches at the Freedom Radio (Early 1980s)]. Svoboda, 26.08 2014. Available at: https://www.svoboda.org/a/26572124. html (accessed 29 December 2020). (In Russian) 
Tsyrkun S. (2006) Ul'tra-si: sportivnoe kino kak chast' sovetskoj mifologii [Ultra-si: Sports Cinema as Part of Soviet Mythology]. Iskusstvo kino, no. 11. (In Russian)

Turkulets S. (2010) Pravo i social'nyj porjadok v kontekste social'nogo proektirovanija. [Law and Social Order in the Context of Social Design]. Sociology of Power, no 1, pp. 173-182. (In Russian)

Vinogradov P. (1979) Ispol'zovanie kino v propagande fizicheskoj kul'tury i sporta [The Use of Cinema in the Promotion of Physical Culture and Sport], Moscow: Obshchestvo Znanie. (In Russian)

Vlasov Y. (1986) Zachem nam nuzhen sport? [Why do We Need Sport?]. Sovetskaya kultura, December 9. (In Russian)

Vogler C. (1985) A Practical Guide to Joseph Cambell's The Hero with a Thousand Faces. Unpublished paper.

Weed M., Coren E., Fiore J., Wellard I., Chatziefstathiou D., Mansfield L., Dowse S. (2015) The Olympic Games and Raising Sport Participation: A Systematic Review of Evidence and an Interrogation of Policy for a Demonstration Effect. European Sport Management Quarterly, vol. 15, no 2, pp. 195-226.

Zlodoreva A. (1966) Sport glazami kino [Sports through Eyes of Cinema], Moscow: Physical Culture and Sport. (In Russian)

\title{
Создавая героя... смеясь над паяцами? Репрезентация спорта и физкультуры в советском кино после олимпийского разворота в политике
}

\author{
Андрей Адельфинский \\ Кандидат экономических наук, доцент, Московский государственный технический университет \\ им. Н. Э. Баумана \\ Адрес: 2-я Бауманская ул., д. 5, стр. 1, Москва, Российская Федерация 105005 \\ E-mail: adelfi@mail.ru
}

В 1940-1960-х гг. СССР совершил «идеологический» поворот от левой спортивной политики к борьбе за олимпийские достижения. Как это коренное изменение повлияло на социальный порядок советского спорта и его представление в искусстве? В работе представлен систематический обзор советских спортивных игровых фильмов. Изучая репрезентации физической культуры и спорта, мы соотносили взгляд искусства и социальный контекст. Сосредоточившись на 1950-1980-х годах, мы нашли три разных презентации. №1: Создавая героя (элитные спортсмены) - художественные фильмы о спорте, в которых строится миф о герое. Прославляя элитный спорт, российские фильмы 2010-х гг. фактически лишь продолжают старую традицию. № 2: Смеясь над паяцем (атлеты-любители) художественные фильмы на общие темы, в которых упоминаются рекреационные занятия спортом (т.е. фитнес, неэлитный спорт). Удивительно, но этот спорт представлен в комическом смысле (исключая альпинизм и туризм). № 3: Реалии спорта — это наименьшая подборка фильмов, где искусство отражало реальную ситуацию в советской спортивной 
индустрии. Критикуется практика лжелюбительства, глубоко укоренившаяся в СССР; эксчемпионы представлены как антигерои, неспособные вписаться в реальную жизнь, и т.п. Мы полагаем, что с 1970-х гг. спортивное кино уже не работало на пропаганду массового спорта. При этом элитный спорт (сам по себе как ветвь искусства), его репрезентации в официальном искусстве и медиа - совместно сконструировали великий «евангелический» миф о себе, который стал частью общественного сознания. Однако этот миф не имел ничего общего с преобразованной реальностью. Представление элитного спорта было лишь инструментом пропаганды и создавало вымышленный социальный мир. Иррациональность существующего общественного строя критически отразилась только в жанре комедии.

Ключевые слова: спортивная политика, спорт в искусстве, советское кино, социальный заказ, советский спорт, спортивная пирамида, спорт высших достижений, спорт для всех 